\title{
Effects of Nanofertilizers (Mg and Fe) and Planting Data on Productivity and Quality of Potato Tubers in Cold Desert Climate
}

Amir Khodadadi Karooki ${ }^{1}$

Mohammadreza Yavarzadeh

Mohammad Mehdi Akbarian ${ }^{3}$

Ali Akbar Askari ${ }^{4}$

\section{Abstract}

Interaction among nanofertilizers supply and planting data may yield synergistic outputs that could influence nutrient use efficiency. To provide insight on this phenomenon, a double split plot based on RCBD with 3 replications were laid out to evaluate the effects spraying solution of nanoparticles magnesium (Mg) and iron (Fe); $0.0 \%, 1.0 \%$, and $2.0 \%$ at flowering and tuber filling stages) and planting data (October 5, 2019 and October 25, 2019) on bioelements, protein nitrogen, and nitrates contents of Sante potato tubers in a cold desert climate (Kerman, Iran). Considering the control group, the use of different dosages of nanofertilizers resulted in a significant increase in the bioelements and $\mathrm{pH}$ contents. Besides effects of area and time of planting, their two and three effects on tuber chlorophyll contents were reported significant. The highest protein and nitrogen portion of the potato tubers were related to spraying solution of $\mathrm{Mg}(1.0 \%)+\mathrm{Fe}(2.0 \%)$ nanofertilizers. Increasing nanofertilizers supplementation reduced the nitrate content of potato tubers. The results indicated that the application of nanofertilizers significantly increased the carotenoid portion of the potato tubers. The interaction effects of nanofertilizers and planting data on chlorophyll index and calcium levels of potato tubers were completely significant. Our analysis corroborated that application nanofertilizers by spraying during flowering and tuber filling stages enhances potato productivity and quality by improving bioelements or resulting in favorable physiological outcomes and is recommended to farmers.

Keywords: Bioelements. Sante potato tubers. Nanofertilizers. Nitrate. Planting data. Iran.

\section{Introduction}

The world population continues to grow rapidly. Likewise, in recent years the growth rates of world agricultural production and crop yields have slowed. This has raised fears that the world may not be able to grow enough food and other commodities to ensure that future populations are adequately fed (FAO, 2015). To overcome this phenomenon and to achieve food security, the research has aimed to clarify the effect of fertilization with nanofertilizers on efficient agronomic production.

Nowadays, how nanofertilizers affect crop yields and physiological outcomes in crop species under varying area conditions remain particularly interesting questions to be addressed. Nanotechnology helps to improve agricultural production by increasing the efficiency of inputs and minimizing relevant losses.

1 Islamic Azad University, Bam, Iran. Department of Agriculture. PhD Candidate. amirkh13611408@gmail.com

2 Islamic Azad University, Bam, Iran. Department of Agriculture. Assistant Professor. dr.yavarzadeh@iaubam.ac.ir (Correspondence)

3 Islamic Azad University, Bam, Iran. Department of Agriculture. Assistant Professor. maat121@yahoo.com

4 Islamic Azad University, Bam, Iran. Department of Agriculture. Assistant Professor. mazdakask@yahoo.com 
Also, nanomaterials as unique carriers of agrochemicals facilitate the site-targeted controlled delivery of nutrients with increased crop protection (SHANG et al., 2019; TABARRAEl et al., 2019).

Potato (Solanum tuberosum L.) is widely used for many food and industrial applications and is considered one of the most significant crops in moderate to cold regions (BIRCH et al., 2012). Some previous studies reported that the application of nanofertilizers plays a dominant role in the course of growth and development processes, shaping the volume and quality of potato yields (especially at flowering and tuber filling stages) (ZENGIN et al., 2008; POBEREZNY; WSZELACZYNSKA, 2011; WANG et al., 2020), which are safe to consumers' health.

Magnesium (Mg) and iron (Fe) are involved in metabolic processes and these are considered activators of important key enzymes (MENGAL; KIRKBY, 2001; EMAMI and OLFATI, 2017). Mg plays a part in energy transfer, in the absorbing of water by the way of organizing of osmotic pressure in the cell and cell growing (ZENGIN et al., 2008). Generally, Mg fertilization improves crop yield in most production systems. The deficiency of which affects photosynthesis and carbohydrate partitioning in crops (NEJIA et al., 2016) reduces the sustainability of agricultural production and development (JEROEN et al., 2015). The conflicting response of yield and quality traits of potato to increasing Mg supply may serve as an example (GERENDAS; FUHRS, 2013). Also, it has been estimated that more than $60 \%$ of the world's population is Fe dietary deficient (WHITE; BROADLEY, 2009). Fe is an essential element for crop yields. Fe deficiency is a common nutritional disorder in many crop plants, causing chlorosis, poor yields, and reduced nutritional quality (AL-JOBORI; AL-HADITHY, 2014).

Potato tubers have a low tendency to accumulate nitrates (WRONIAK, 2006; HMELAK et al., 2014). Nitrates content in consumable plant organs is small and should not raise concern provided that the recommended fertilization and harvest terms of the original plants are observed (POBEREZNY et al., 2014).

The present study aimed to determine the effects of nanofertilizers ( $\mathrm{Mg}$ and Fe from spraying solution) and planting date on the bioelements compounds and the protein nitrogen and nitrates content in potato tubers in a local cold desert climate that higher nutritional demand.

\section{Materials and methods}

\section{Soil analysis}

Soil samples in 0-30 cm deep were collected, air-dried, crushed, and sieved through a $2 \mathrm{~mm}$ sieve, and analyzed for the physicochemical properties with Ostrowska, Gawliñski, and Szczubiaka methods (1991).

Table 1 - Some physicochemical properties of the soil used (2019): Electrical conductivity (EC) in ds $\mathrm{m}^{-1}, \mathrm{pH}$, percentage of silt, sand, and clay, soil texture, organic matter (OM) in percentage (\%). Nitrogen (N), Phosphorus (P), Potassium (K), Iron (Fe), Magnesium (Mg) in $\mathrm{g} \mathrm{kg}^{-1}$ Kerman, Iran (2019).

\begin{tabular}{|c|c|c|c|c|c|c|c|c|c|c|c|c|}
\hline \multirow{2}{*}{ Area } & \multirow{2}{*}{$\mathrm{EC}\left(\mathrm{ds} \mathrm{m}^{-1}\right)$} & \multirow{2}{*}{$\mathrm{pH}$} & \multicolumn{3}{|c|}{ Soil property (\%) } & \multirow{2}{*}{ Soil texture } & \multirow{2}{*}{ OM (\%) } & \multicolumn{5}{|c|}{ Elements ( $\mathrm{g} \mathrm{kg}^{-1}$ ) } \\
\hline & & & Silt & Clay & Sand & & & $\mathbf{N}$ & $\mathbf{P}$ & $K$ & $\mathrm{Fe}$ & $\mathrm{Mg}$ \\
\hline Zeh-e Kalut & 1.8 & 7.7 & 29 & 33 & 38 & Sandy soil & 0.59 & 0.06 & 12 & 135 & 2.6 & 3.2 \\
\hline Islamabad & 1.8 & 7.9 & 39 & 28 & 33 & Sandy soil & 0.59 & 0.06 & 13 & 140 & 2.2 & 3.1 \\
\hline
\end{tabular}

Source: Central Agriculture Laboratory, Bam Islamic Azad University (2019).

A double split plot based on randomized complete block design with 3 replications were laid out to determine the effects of spraying a solution of nanoparticles $\mathrm{Mg}$ and $\mathrm{Fe}(0,1$, and $2 \%$ at 
flowering and tuber filling stages) and planting data (October 5, 2019 and 25 October 25, 2019) on bioelements (Nitrogen (N), Potassium (K), Calcium (Ca), Sodium (Na), Phosphorus (P) and Iron (Fe)) and protein nitrogen and nitrates contents of Sante potato tubers in a cold desert climate (Kerman, Iran). Field experiments were carried out at the farms of Islamabad and Zeh-e Kalut Station (TABLE 2).

Table 2 - Geographical condition of areas (Kerman, Iran; 2019)

\begin{tabular}{cccc}
\hline Area & Longitude & Latitude & Sea level \\
\hline Zeh-e Kalut & $27 " 14 " 51$ & $56 " 35 " 56$ & 22751 \\
Islamabad & $27 " 47 " 27$ & $58 " 35 " 34$ & 386 \\
\hline
\end{tabular}

Source: Meteorological Organization, Tehran, Iran (2019)

The first spraying solution of nanoparticles was performed after the rows became compact and potato plants formed first floral buds, and the following treatments took place at 7-day intervals. Once the potato had completed their vegetative growth, potato tubers were collected and samples were fragmented, dried at $70^{\circ} \mathrm{C}$, and stored in sealed containers.

The concentration of bioelements was measured with a mix of Hydrochloric acid and Nitric acid solutions using standard methods derived from Westerman (1990). P concentration was measured with Spectrophotometric methods (RYAN; STEFAN; RASHID, 2001), and other elements were measured by atomic absorption methods (JONES, 2001).

Total and protein nitrogen contents were determined with Kjeldhal's methods. In brief, $24 \%$ solution of trichloroacetic acid was used for titration of proteins to determine protein nitrogen. The content of nitrates was measured using the ion-selective methods (multi-purpose computer device CX-721, Elmetron).

\section{Statistical analysis}

Statistical analysis was performed using SPSS 17.0 software (2008). The results were expressed as mean \pm standard deviation (SD) and performed with one-way analysis of variance (ANOVA) followed by Dunnett's new multiple range test and values of $p<0.05$ were considered as statistically significant.

\section{Results and discussion}

The bioelements content in potato tubers was significantly affected by the experimental factors and their interaction (TABLES 3 and 4). The lowest concentration of bioelements was determined in the potato tubers harvested in the control group (in which only distilled water had been applied). Considering the control group, the use of different dosages of nanofertilizers resulted in a significant increase in the bioelements concentration (including $\mathrm{K}, \mathrm{Ca}$, and $\mathrm{Fe})(\mathrm{p}<0.05)$. In this study, the highest Fe and $\mathrm{Ca}$ contents were recorded in the potato tubers treated with $\mathrm{Mg}(1.0 \%)+\mathrm{Fe}(2.0 \%)$ spraying solution.

Two and three effects of area and time of planting on tuber chlorophyll contents were reported significant (TABLES 5 and $6, \mathrm{p}<0.01$ ). Likewise, the interaction effects of nanofertilizers and planting data on chlorophyll index and Ca levels of potato tubers were completely significant $(p<0.05)$. 
Table 3 - Effects of nanoparticles and planting data on bioelements contents (\%) of Sante potato tubers (Kerman, Iran; 2019): Nitrogen (N), Phosphorus (P), Potassium (K), Iron (Fe), Magnesium (Mg) in g kg-1. Kerman, Iran (2019); $\mathrm{p}<0.05$.

\begin{tabular}{lccccc}
\hline \multicolumn{1}{c}{ Treatments } & $\mathrm{K}$ & $\mathrm{Na}$ & $\mathrm{Ca}$ & $\mathbf{P}$ & $\mathbf{F e}$ \\
\hline Area & & & & & \\
Zeh-e Kalut & $1.9^{\mathrm{a}}$ & $1.64^{\mathrm{a}}$ & $0.09^{\mathrm{a}}$ & $0.072^{\mathrm{a}}$ & $33.35^{\mathrm{a}}$ \\
Islamabad & $1.84^{\mathrm{a}}$ & $1.50^{\mathrm{a}}$ & $0.09^{\mathrm{a}}$ & $0.070^{\mathrm{a}}$ & $33.22^{\mathrm{a}}$ \\
Cultivar time & & & & \\
5 October & $1.88^{\mathrm{a}}$ & $1.98^{\mathrm{a}}$ & $0.09^{\mathrm{a}}$ & $0.070^{\mathrm{a}}$ & $33.17^{\mathrm{a}}$ \\
25 October & $1.85^{\mathrm{a}}$ & $1.93^{\mathrm{a}}$ & $0.09^{\mathrm{a}}$ & $0.070^{\mathrm{a}}$ & $33.4^{\mathrm{a}}$ \\
Spraying solution & & & & & \\
Control & $1.75^{\mathrm{b}}$ & $1.66^{\mathrm{a}}$ & $0.07^{\mathrm{e}}$ & $0.056^{\mathrm{a}}$ & $29.38^{\mathrm{c}}$ \\
$1 \% \mathrm{Fe}$ & $1.84^{\mathrm{ab}}$ & $1.69^{\mathrm{a}}$ & $0.08^{\mathrm{d}}$ & $0.058^{\mathrm{a}}$ & $32.8^{\mathrm{b}}$ \\
$2 \% \mathrm{Fe}$ & $2.01^{\mathrm{a}}$ & $1.74^{\mathrm{a}}$ & $0.09^{\mathrm{c}}$ & $0.060^{\mathrm{a}}$ & $32.6^{\mathrm{b}}$ \\
$1 \% \mathrm{Mg}$ & $1.84^{\mathrm{ab}}$ & $1.71^{\mathrm{a}}$ & $0.07^{\mathrm{b}}$ & $0.073^{\mathrm{a}}$ & $32.18^{\mathrm{b}}$ \\
$2 \% \mathrm{Mg}$ & $1.79^{\mathrm{b}}$ & $1.69^{\mathrm{a}}$ & $0.09^{\mathrm{a}}$ & $0.077^{\mathrm{a}}$ & $32.24^{\mathrm{b}}$ \\
$1 \% \mathrm{Fe} * 1 \% \mathrm{Mg}$ & $1.9^{\mathrm{ab}}$ & $1.75^{\mathrm{a}}$ & $0.10^{\mathrm{b}}$ & $0.091^{\mathrm{a}}$ & $33.71^{\mathrm{b}}$ \\
$1 \% \mathrm{Fe} * 2 \% \mathrm{Mg}$ & $1.76^{\mathrm{b}}$ & $1.72^{\mathrm{a}}$ & $0.11^{\mathrm{a}}$ & $0.096^{\mathrm{a}}$ & $32.6^{\mathrm{b}}$ \\
$2 \% \mathrm{Fe} * 1 \% \mathrm{Mg}$ & $1.93^{\mathrm{ab}}$ & $1.70^{\mathrm{a}}$ & $0.10^{\mathrm{a}}$ & $0.093^{\mathrm{a}}$ & $37.03^{\mathrm{a}}$ \\
$2 \% \mathrm{Fe} * 2 \% \mathrm{Mg}$ & $1.99^{\mathrm{a}}$ & $1.78^{\mathrm{a}}$ & $0.11^{\mathrm{a}}$ & $0.099^{\mathrm{a}}$ & $36.89^{\mathrm{a}}$ \\
\hline
\end{tabular}

ns: non-significant; The letters (a-d) show a significant difference between groups

Source: Elaborated by the authors (2021).

Table 4 - Interaction between area * time cultivar * spraying solution applications on bioelements content of Sante potato tubers (Kerman, Iran; 2019); ): Nitrogen (N), Phosphorus (P), Potassium (K), Iron (Fe), Magnesium (Mg) in $\mathrm{g} \mathrm{kg}^{-1} \cdot$ Kerman, Iran (2019); $\mathrm{p}<0.05$.

\begin{tabular}{|c|c|c|c|c|c|c|}
\hline \multirow[t]{2}{*}{ Source of changes } & \multirow[t]{2}{*}{ Df } & \multicolumn{3}{|c|}{ Average of squares } & \multirow[b]{2}{*}{$\mathbf{P}$} & \multirow[b]{2}{*}{$\mathrm{Fe}$} \\
\hline & & $\mathrm{K}$ & $\mathrm{Na}$ & $\mathrm{Ca}$ & & \\
\hline Area & 1 & 0.09 ns & $2447 / 6$ ns & $0.000003^{n s}$ & $0.004^{\text {ns }}$ & $0.46^{\text {ns }}$ \\
\hline Original error & 4 & 0.33 & $6619 / 4$ & 0.003 & 0.003 & 50.42 \\
\hline Time cultivar & 1 & $0.03^{\text {ns }}$ & $120.05^{\text {ns }}$ & $0.0002 *$ & $0.001^{\mathrm{ns}}$ & $1.43^{\text {ns }}$ \\
\hline Area * Time cultivar & 1 & $0.001^{\text {ns }}$ & $220.6^{\mathrm{ns}}$ & 0.00001 ns & $0.004^{\mathrm{ns}}$ & $1.644^{\mathrm{ns}}$ \\
\hline Minor error & 4 & 0.02 & 2970.6 & 0.0004 & 0.002 & 9.36 \\
\hline Spraying solution & 8 & $0.11 * *$ & $1121 / 1$ ns & $0.002 * *$ & $0.005^{\mathrm{ns}}$ & $68.63 * *$ \\
\hline Area * Spraying solution & 8 & 0.01 ns & $1092 / 7$ ns & 0.0001 * & 0.0007 ns & $9.1^{\mathrm{ns}}$ \\
\hline Time cultivar * Spraying solution & 8 & 0.01 ns & $773.5^{\mathrm{ns}}$ & $0.0001 *$ & 0.001 ns & $19.25^{\mathrm{ns}}$ \\
\hline Area * Time cultivar * Spraying solution & 8 & 0.01 ns & $741.2^{\mathrm{ns}}$ & 0.00005 ns & $0.003^{\text {ns }}$ & 6.31 ns \\
\hline Minor error error & 64 & 0.03 & 940.4 & 0.00005 & 0.002 & 9.9 \\
\hline CV\% & - & 10.01 & 18.5 & 8.2 & 17.4 & 9.4 \\
\hline
\end{tabular}

* : $p<0.05,{ }^{* *}: p<0.01$, ns : non-significant

Source: Elaborated by the authors (2021). 
Table 5 - Effects of nanoparticles and planting data on chlorophyll index and photosynthetic pigments (mg g-1 fresh leaves) of Sante potato tubers (Kerman, Iran; 2019); $\mathrm{p}<0.05$.

\begin{tabular}{lccc}
\hline \multicolumn{1}{c}{ Treatments } & Chlorophyll index & Chlorophyll a & Chlorophyll b \\
\hline Area & & & \\
Zeh-e Kalut & $42.9^{\mathrm{a}}$ & $30.28^{\mathrm{a}}$ & $20.4^{\mathrm{a}}$ \\
Islamabad & $40.9^{\mathrm{a}}$ & $27.3^{\mathrm{a}}$ & $17.85^{\mathrm{a}}$ \\
Cultivar time & & & \\
5 October & $42.36^{\mathrm{a}}$ & $29.33^{\mathrm{a}}$ & $19.79^{\mathrm{a}}$ \\
25 October & $41.44^{\mathrm{b}}$ & $28.2^{\mathrm{b}}$ & $18.46^{\mathrm{a}}$ \\
Spraying solution & & & \\
Control & $35.93^{\mathrm{g}}$ & $22.24^{\mathrm{e}}$ & $13.42^{\mathrm{d}}$ \\
$1 \% \mathrm{Fe}$ & $39.4^{\mathrm{e}}$ & $25.7^{\mathrm{d}}$ & $15^{\mathrm{d}}$ \\
$2 \% \mathrm{Fe}$ & $41.87^{\mathrm{d}}$ & $28.18^{\mathrm{c}}$ & $17.64^{\mathrm{c}}$ \\
$1 \% \mathrm{Mg}$ & $38.04^{\mathrm{f}}$ & $24.35^{\mathrm{d}}$ & $14.5^{\mathrm{d}}$ \\
$2 \% \mathrm{Mg}$ & $41.11^{\mathrm{d}}$ & $27.61^{\mathrm{c}}$ & $20.85^{\mathrm{b}}$ \\
$1 \% \mathrm{Fe} * 1 \% \mathrm{Mg}$ & $43.85^{\mathrm{c}}$ & $30.35^{\mathrm{b}}$ & $26.47^{\mathrm{a}}$ \\
$1 \% \mathrm{Fe} * 2 \% \mathrm{Mg}$ & $41.76^{\mathrm{d}}$ & $34.1^{\mathrm{a}}$ & $23.16^{\mathrm{b}}$ \\
$2 \% \mathrm{Fe} * 1 \% \mathrm{Mg}$ & $46.51^{\mathrm{b}}$ & $32.66^{\mathrm{a}}$ & $23.2^{\mathrm{b}}$ \\
$2 \% \mathrm{Fe} * 2 \% \mathrm{Mg}$ & $48.51^{\mathrm{a}}$ & $34.08^{\mathrm{a}}$ & \\
\hline
\end{tabular}

ns: non-significant; The letters (a-d) show a significant difference between groups

Source: Elaborated by the authors (2021).

Table 6 - Interaction between area * time cultivar * spraying solution application on chlorophyll index and photosynthetic pigments of Sante potato tubers (Kerman, Iran; 2019).

\begin{tabular}{|c|c|c|c|c|c|}
\hline \multirow[t]{2}{*}{ Source of Changes } & \multirow[t]{2}{*}{ Df } & \multicolumn{4}{|c|}{ Average of squares } \\
\hline & & Chlorophyll index & Chlorophyll a & Chlorophyll b & Carotenoid \\
\hline Area & 1 & $108.6 * *$ & $234.9 * *$ & $0.78^{\mathrm{ns}}$ & $176.5 * *$ \\
\hline Original error & 4 & 284.84 & 270.6 & 4.16 & 300.5 \\
\hline Time cultivar & 1 & $22.87 * *$ & 29.14 * & 0.82 ns & 47.9 * \\
\hline Area * Time cultivar & 1 & 1.84 ns & 0.26 ns & 1.04 ns & 0.52 ns \\
\hline Minor error & 4 & 2.38 & 2.17 & 24.03 & 6.79 \\
\hline Spraying solution & 8 & 189.42 * & $221.3 * *$ & 6.73 ns & $246.8 * *$ \\
\hline Area* Spraying solution & 8 & $7.89 * *$ & 11.36 * & 3.47 ns & 9.19 ns \\
\hline Time cultivar * Spraying solution & 8 & $10.23 * *$ & 15.24 ** & 3.45 ns & 13.68 ns \\
\hline Area * Time cultivar * Spraying solution & 8 & $11.72 * *$ & 7.09 ns & $5.48^{\text {ns }}$ & $6.1^{\mathrm{ns}}$ \\
\hline Minor error & 64 & 2.16 & 5.08 & 4.5 & 8.84 \\
\hline CV\% & - & 3.51 & 7.82 & 21.6 & 15.54 \\
\hline
\end{tabular}

ns: non-significant; The letters (a-d) show a significant difference between groups.

Source: Elaborated by the authors (2021).

In this study, the dosage of nanofertilizers $(0.0 \%, 1.0 \%$, and $2.0 \%$ at flowering and tuber filling stages) used significantly decreased the content of nitrates in potato tubers (TABLES 7 and 8 , $\mathrm{p}<0.05$ ). The highest decrease in nitrate content was obtained at the $2.0 \%$ and $1.0 \%$ nanofertilizers treatments. These groups were divided into a single statistical group and showed difference with 
other groups. Increasing nanofertilizers supplementation amplification of $\mathrm{pH}$ contents of potato tubers $(p>0.05)$. The results indicated that the application of nanofertilizers significantly increased the carotenoid portion of the potato tubers $(p<0.05)$.

Table 7 - Effects of nanoparticles and planting data on $\mathrm{Fe}(\mathrm{mg} / \mathrm{kg})$, nitrogen $(\%)$, nitrates $(\mathrm{mg} / \mathrm{kg})$ and $\mathrm{pH}$ of Sante potato tubers (Kerman, Iran; 2019); $p<0.05$

\begin{tabular}{|c|c|c|c|c|}
\hline Treatments & Protein & Nitrogen & Nitrates & $\mathrm{pH}$ \\
\hline \multicolumn{5}{|l|}{ Area } \\
\hline Zeh-e Kalut & $210.7^{a}$ & $0.7^{a}$ & $210.7^{a}$ & 4.39 a \\
\hline Islamabad & $203.11^{a}$ & $0.67^{a}$ & $203.11^{a}$ & $3.84^{a}$ \\
\hline \multicolumn{5}{|l|}{ Cultivar time } \\
\hline 5 October & $201.96^{a}$ & 0.69 a & $201.96^{a}$ & $4.15^{a}$ \\
\hline 25 October & $211.85^{a}$ & $0.68^{a}$ & $211.85^{a}$ & $4.07^{a}$ \\
\hline \multicolumn{5}{|l|}{ Spraying solution } \\
\hline Control & $237.5^{a}$ & $0.55^{f}$ & $237.5^{a}$ & $3.48^{g}$ \\
\hline $1 \% \mathrm{Fe}$ & $224.2 \mathrm{ab}$ & 0.61 de & $224.2 \mathrm{ab}$ & 3.83 ef \\
\hline $2 \% \mathrm{Fe}$ & 207.3 bcd & $0.66^{c d}$ & 207.3 bcd & 4.06 de \\
\hline $1 \% \mathrm{Mg}$ & 206.7 bcd & 0.59 ef & 206.7 bcd & $3.69 \mathrm{fg}$ \\
\hline $2 \% \mathrm{Mg}$ & $194.9^{\mathrm{cd}}$ & $0.74^{\mathrm{b}}$ & $194.9^{\mathrm{cd}}$ & $4.43^{b c}$ \\
\hline $1 \% \mathrm{Fe} * 1 \% \mathrm{Mg}$ & $204.1 \mathrm{bcd}$ & $0.71 \mathrm{bc}$ & $204.1 \mathrm{bcd}$ & $4.21^{\mathrm{cd}}$ \\
\hline $1 \% \mathrm{Fe} * 2 \% \mathrm{Mg}$ & $213.7 \mathrm{abc}$ & $0.67^{\mathrm{cd}}$ & $213.7 \mathrm{abc}$ & $4.07 \mathrm{de}$ \\
\hline $2 \% \mathrm{Fe} * 1 \% \mathrm{Mg}$ & $187.34 \mathrm{~cd}$ & $0.84^{a}$ & $187.34^{\mathrm{cd}}$ & $4.52 \mathrm{ab}$ \\
\hline $2 \% \mathrm{Fe} * 2 \% \mathrm{Mg}$ & $186.3^{d}$ & $0.8^{a}$ & $186.3^{d}$ & $4.72^{a}$ \\
\hline
\end{tabular}

ns: non-significant; The letters (a-d) show a significant difference between groups

Source: Elaborated by the authors (2021).

Table 8 - Interaction between area * time cultivar * spraying solution application on nitrogen, nitrates and $\mathrm{pH}$ contents of Sante potato tubers (Kerman, Iran; 2019).

\begin{tabular}{|c|c|c|c|c|c|}
\hline \multirow[t]{2}{*}{ Source of Changes } & \multirow[b]{2}{*}{ Df } & \multirow[b]{2}{*}{ Protein } & \multicolumn{3}{|c|}{ Average of squares } \\
\hline & & & Nitrogen & Nitrates & $\mathrm{pH}$ \\
\hline Area & 1 & 1.06 * & 0.02 * & 1557.3 ns & $8.16 * *$ \\
\hline Original error & 4 & 2.28 & 0.05 & 12631.7 & 5.66 \\
\hline Time cultivar & 1 & $0.1^{\mathrm{ns}}$ & 0.001 ns & 2640.4 * & 0.16 ns \\
\hline Area * Time cultivar & 1 & 0.06 ns & 0.001 ns & 3.68 ns & 0.02 ns \\
\hline Minor error & 4 & 0.09 & 0.002 & 2734.5 & 0.01 \\
\hline Spraying solution & 8 & $4.35 * *$ & $0.11 * *$ & $3370.1 * *$ & $1.95 * *$ \\
\hline Area * Spraying solution & 8 & $0.13^{\mathrm{ns}}$ & $0.003^{\mathrm{ns}}$ & 992.9 ns & 0.09 ns \\
\hline Time cultivar * Spraying solution & 8 & $0.16^{\text {ns }}$ & $0.004^{\mathrm{ns}}$ & 379.22 ns & $0.11^{\text {ns }}$ \\
\hline $\begin{array}{l}\text { Area * Time cultivar * Spraying } \\
\text { solution }\end{array}$ & 8 & 0.19 ns & $0.005^{\text {ns }}$ & 457.9 ns & 0.09 ns \\
\hline Minor error & 64 & 0.17 & 0.004 & 829.7 & 0.08 \\
\hline CV\% & - & 9.62 & 9.68 & 13.9 & 7.26 \\
\hline
\end{tabular}

ns: non-significant; The letters (a-d) show a significant difference between groups.

Source: Elaborated by the authors (2021). 
As reported, due to the metabolic processes role of $\mathrm{Mg}$ and Fe elements in the synthesis of proteins and activators of important enzymes (MENGEL; KIRKBY, 2001), thus utilization of nanofertilizers containing these elements could increase potato productivity and quality. Our findings are well coordinated by the current literature on nanofertilizers productivity, indicating that these nanofertilizers ( $\mathrm{Mg}$ and Fe) can cause an improvement of the nutritional values of the Sante cultivar. In this study, the management of nanofertilizers is a critical component of potato tubers production systems as potato has a relatively high $\mathrm{Mg}$ and Fe requirement and inefficiently uses soil these elements in the cold desert climate of Iran. It is the main component of chlorophyll and activates metabolic reactions of plants (GERENDAS; FUHRS, 2013). Also, the application of nanofertilizers resulted in higher concentrations of bioelements including $\mathrm{N}, \mathrm{K}, \mathrm{Ca}, \mathrm{Na}, \mathrm{P}$, and Fe ions in the harvested potato tubers improving their nutritional values. In this study, the bioelements contents of the potato tubers were appropriate. This improvement was obtained because of the positive effect of nanofertilizers on bioelements compounds and the protein nitrogen and nitrates portions of potato tubers. In agreement with the present result, some authors observed application of micronutrients mixture (like $\mathrm{K}, \mathrm{Fe}, \mathrm{Mg}, \mathrm{Cu}, \mathrm{Zn}$ ) during flowering improved the nutritional values of potato tubers (ZENGIN et al., 2008; AL-JOBORI; AL-HADITHY 2014). The nutritional quality of potato tubers is cultivar-specific and depends on climate-soil conditions and agrotechnical practices, as well as the conditions during long-term storage (WSZELACZYNSKA et al., 2020). Kohnaward, Jalilian, and Pirzad (2012) showed that micronutrients increase photosynthesis rate and improve leaf area duration. Also, adequate micronutrients are essential for optimizing tuber yield, solids content, nutritional quality, and resistance to some diseases (ROSEN et al. 2014).

Zenggin et al. (2008) reported that every two years in all locations effects of fertilizers used on tuber yields, tuber size distribution, dry matter content of tuber and $\mathrm{K}, \mathrm{Mg}$, and $\mathrm{S}$ contents of leaves were significantly changed depending on the locations. Similarly, based on our results the chemical composition of potato tubers, affecting their quality can be improved by the location (Islamabad and Zeh-e Kalut) both during flowering and tuber filling stages (TABLES 3 and 4).

Results of this research revealed that the highest protein and nitrogen portions of the potato tubers were related to spraying solution of nanofertilizers in Zeh-e Kalut area (October 25, 2019). The rate of crop growth is modified by nitrogen application, and its use may depend to a large extent on the supply of Mg and sulfur to plants (POBEREZNY; WSZELACZYNSKA, 2011). This is slightly different from the results reported by Rogozinska et al. (2005), who discovered that, besides nitrogen fertilization, applications of larger quantities of $\mathrm{Mg}$ also led to lowered total nitrogen contents in potato tubers. Also, Ciecko, Zolnowski, and Mierzejwska (2010) reported that Mg nutrition, either as foliar or soil treatments, did not have any significant influence on the content of total and protein nitrogen in potato tubers. As reported in the Fertilizer Handbook (EAKIN, 1972), more elements supplied by fertilizers may result in different fertilizer applications on the tuber yield and quality. This diversity may be due to the differences in production systems, potato cultivars, locations, and kinds of mineral fertilization (MENGEL; KIRKBY, 2001).

The results suggested to over-accumulation of nitrates substances in Sante potato tubers is depended on the area conditions and agro-technical practices like spraying solution of nanoparticles including $\mathrm{Mg}$ and Fe. Application of nanofertilizers sprayed over leaves tended to lower the concentration of nitrates in potato tubers. Also, the experiment found that the content of nitrates in potato tubers ranged from 237 (control) to $186 \mathrm{mg} \mathrm{kg}^{-1}$ (2.0 \% Fe $+2.0 \% \mathrm{Mg}$ ). Similar results were stated by lerna (2009) and Rytel (2012), who found that the content of nitrates is especially affected by fertilization of the mineral and cultivar. On contrary, when nanofertilizers were introduced to soil, they raised the content of nitrates in potato tubers (CIECKO; ZOLNOWSKI; MIERZEJWSKA, 2010). 


\section{Conclusions}

Our analysis corroborated that application nanofertilizers by spraying during flowering and tuber filling stages enhances potato productivity, decreases nitrate contents and quality by improving bioelements or resulting in favorable physiological outcomes, and is recommended to farmers.

\section{Acknowledgments}

The authors would like to acknowledge Prof. Dr. Ali Olfati (A.Olfati65@Gmail.Com), for all efforts to improve the English written language of the paper.

\section{Efeitos de Nanofertilizantes (Mg e Fe) e Dados de Plantio na Produtividade e Qualidade de Tubérculos de Batata em Clima de Deserto Frio}

\section{Resumo}

A interação entre o suprimento de nanofertilizantes e os dados de plantio podem gerar resultados sinérgicos que podem influenciar a eficiência do uso de nutrientes. Para fornecer uma visão sobre este fenômeno, um gráfico de divisão duplo baseado em Delineamento de Blocos Completos Casualizados (RCBD), com 3 repetições, foi estabelecido para avaliar os efeitos da solução de pulverização de nanopartículas de magnésio ( $\mathrm{Mg}$ ) e ferro ( $\mathrm{Fe}$ ); 0,0 \%, 1,0 \% e 2,0 \% nas fases de floração e enchimento de tubérculos e dados de plantio ( 5 de outubro de 2019 e 25 de outubro de 2019) em bioelementos, nitrogênio proteico e conteúdo de nitratos de tubérculos de batata Sante em um clima desértico frio (Kerman , Irã). Considerando o grupo controle, o uso de diferentes dosagens de nanofertilizantes resultou em aumento significativo nos teores de bioelementos e pH. Além dos efeitos de área e época de plantio, seus dois e três efeitos sobre os teores de clorofila nos tubérculos foram relatados como significativos. A maior porção de proteína e nitrogênio dos tubérculos de batata foi relacionada à pulverização de solução de nanofertilizantes de $\mathrm{Mg}(1,0 \%)+\mathrm{Fe}(2,0 \%)$. 0 aumento da suplementação de nanofertilizantes reduziu o teor de nitrato dos tubérculos de batata. Os resultados indicaram que a aplicação de nanofertilizantes aumentou significativamente a porção carotenóide dos tubérculos de batata. Os efeitos de interação de nanofertilizantes e dados de plantio sobre o índice de clorofila e os níveis de cálcio dos tubérculos de batata foram completamente significativos. Nossa análise corroborou que a aplicação de nanofertilizantes por pulverização durante os estágios de floração e enchimento de tubérculos aumenta a produtividade e a qualidade da batata, melhorando os bioelementos ou resultando em resultados fisiológicos favoráveis, sendo recomendada para agricultores.

Palavras-chave: Bioelementos. Tubérculos de batata Sante. Nanofertilizantes. Nitrato. Dados de plantio. Iran.

\section{References}

AL-JOBORI, K. M. M.; AL-HADITHY, S. A. Response of Potato (Solanum Tuberosum) to Foliar Application of Iron, Manganese, Copper and Zinc. Int. J. Agri. Crop. Sci., v. 7, n. 7, p. 358-363, 2014.

BIRCH, P. R. J.; BRYAN, G.; FENTON, B.; GILROY, E. M.; HEIN, I.; JONES, J. T.; PRASHAR, A.; TAYLOR, M. A.; TORRANCE, L.; TOTH, I. K. Crops that feed the world 8: potato: are the trends of increased global production sustainable? Food Security, v. 4, p. 477-508, 2012. 
CIECKO, Z.; ZOLNOWSKI, A. C.; MIERZEJWSKA, A. Effect of Foliar Nitrogen and Magnesium Fertilization on the Total, Protein Nitrogen and Nitrates (V) Content in Potato Tubers. Ecol. Chem. Eng. A. v. 17, n. 6, p. 593-600, 2010.

EAKIN, J. F. Food and Fertilizers. In: The Fertilizer Handbook, The Fertilizer Inst., Washington DC, USA, 1-21, 1972.

EMAMI, S.; OLFATI, A. Effects of dietary supplementing of Spirulina platensis and Chlorella vulgaris microalgae on hematologic parameters in streptozotocin-induced diabetic rats. Iranian J. Pediatr. Hematol. Oncol., v. 7, n. 3, p. 163-170, 2017.

FOOD AND AGRICULTURE ORGANIZATION OF THE UNITED NATIONS. OECD-FAO Agricultural Outlook 2015-2030; OECD/Food and Agriculture Organization of the United Nations: Rome, Italy, 2015.

GERENDÁS, J.; FÜHRS, H. The significance of magnesium for crop quality. Plant. Soil., v. 368, p. 101-128, 2013.

HMELAK, G.A.; URIH, G.; LANGERHOLC, T.; KRISTIL, J. Nitrate content in potatoes cultivated in contaminated groundwater areas. J. Food. Res., v. 3, p. 18-27, 2014.

IERNA, A. Influence of harvest date on nitrate contents of three potato varieties for o-season production. J. Food. Compos. Anal., v. 22, p. 551-555, 2009.

JEROEN, H. F.; DE BAAIJ, A.; JOOST, G. J.; HOENDEROP, C.; RENÉ, J. M.; BINDELS, K. Magnesium in man: implications for health and disease. Physiol. Rev., v. 95, p. 1-46, 2015.

JONES, J. Laboratory Guide for Conducting Soil Tests and Plant Analysis. CRC Press, LLC. USA, 2001.

KOHNAWARD, P.; JALILIAN, J.; PIRZAD, A. Effect of foliar application of Micro-nutrients on yield and yield components of safflower under conventional and ecological cropping systems. Int. Res. J. Appl. Basic. Sci., v. 3, n. 7, p. 1460-1469, 2012.

MENGEL, K.; KIRKBY, E. A. Principles of Plant Nutrition. Kluwer Acad. Publ., Dordrecht, Boston, London, 2001.

NÈJIA, F.; AMINE, E.; WALID, Z.; ABDERRAZAK, S.; CHEDLY, A.; MOKDED, R. Effects of magnesium deficiency on photosynthesis and carbohydrate partitioning. Acta. Physiol. Plant., v. 38, p. 145, 2016.

OSTROWSKA, A.; GAWLIÑSKI, S.; SZCZUBIAKA, Z. Methods of analysis and assessment of soil and plant properties, IOOE, Warszawa, 334, 1991 [In Polish].

POBEREZNY, J.; WSZELACZYNSKA E. Effect of bioelements ( $\mathrm{N}, \mathrm{K}, \mathrm{Mg}$ ) and long-term storage of potato tubers on quantitative and qualitative losses. Part II. Content of dry matter and starch. J. Elementol., v. 16, p. 237-246, 2011.

POBEREŻNY, J.; WSZELACZYŃSKA, E.; WICHROWSKA, D.; JASKULSKI, D. Content of nitrates in potato tubers depending on the organic matter, soil fertilizer, cultivation simplifications applied and storage. Chilean. J. Agri. Res., v. 75, n. 1, p. 42-49, 2014. 
ROGOZINSKA, I.; PAWELZIK, E.; POBEREZNY, J.; DELGADO, E. The effect of different factors on the content of nitrate in some potato varieties. Potato. Res., v. 48, p. 167-180, 2005.

ROSEN, C. J.; KELLING, K. A.; STARK, J. C.; PORTER, G. A. Optimizing Phosphorus Fertilizer Management in Potato Production. Am. J. Potato. Res., v. 2, p. 66-73, 2014.

RYTEL, E. Changes in the levels of glycoalkaloids and nitrates after the dehydration of cooked potatoes.

Am. J. Potato. Res., v. 89, p. 501-507, 2012.

RYAN, J. R.; STEFAN, G.; RASHID, A. Soil and Plant Analysis Laboratory Manual (2 ${ }^{\text {nd }}$ ed). ICARDA. Aleppo, Syria, 172, 2001.

SHANG, Y.; HASAN, M. K.; AHAMMED, G. J.; LI, M.; YIN, H.; ZHOU, J. Applications of Nanotechnology in Plant Growth and Crop Protection: A Review. Molecules., v. 24, p. 2558, 2019.

SPSS Inc. SPSS Statistics for Windows, version 17.0. Chicago: SPSS Inc. 2008.

TABARRAEI, H.; HASSANB, J.; PARVIZA, M. R,; GOLSHAHIC, H.; KESHAVARZ-TARIKHI, H. Evaluation of the acute and sub-acute toxicity of the black caraway seed essential oil in Wistar rats. Toxicol. Reports., v. 6, p. 869-874, 2019.

WANG, Z.; HASSAN, M. U. I.; NADEEM, F.; WU, L.; ZHANG, F.; LI, X. Magnesium Fertilization Improves Crop Yield in Most Production Systems: A Meta-Analysis. Syst. Rev., v. 10, p. 1027. 2020.

WESTERMAN, L. Z. Soil Testing and Plant Analysis. Soil Sci. Soc. Am. Book Ser. 5. Madison, WI, USA, 1990.

WHITE, P. J.; BROADLEY, M. R. Biofortification of crops with seven mineral elements often lacking in 638 human diets-iron, zinc, copper, calcium, magnesium, selenium and iodine. New. Phytol., v. 182, p. 49-84, 2009.

WRONIAK, J. Nutrition qualities of edible potato. Ziemn Pol. v. 6, p. 17-20. 2006. (In Polish).

WSZELACZYŃSKA, E.; POBEREŻNY, J.; KOZERA, W.; KNAPOWSKI, T.; PAWELZIK, E.; SPYCHAJFABISIAK, E. Effect of Magnesium Supply and Storage Time on Anti-Nutritive Compounds in Potato Tubers. Agronomy, v. 10, p. 339, 2020.

ZENGIN, M.; GOKMEN, F.; GEZGIN, S.; ÇAKMAK, I. Effects of different fertilizers with potassium and magnesium on the yield and quality of potato. Asian. J. Chem., v. 20, n. 1, p. 663-676, 2008.

Received: October 4, 2020

Accepted: January 29, 2021 